DANIEL J. B. MITCHELL

University of California, Los Angeles

\title{
Recent Union Contract Concessions
}

SiNCE 1979, union contract concessions have occurred with increasing frequency. Substantial press attention has been devoted to these concessions along with other ills plaguing organized labor such as the declining proportion of union members in the work force and political difficulties with the Reagan administration. Popular accounts of these trends often suggest that a turning point in union wage determination and industrial relations has been reached.

It is clear that the current climate for large wage settlements, both union and nonunion, is unfavorable. The general economic slack since 1979 and the deceleration of price inflation that began in 1981 suggest that the rate of wage increase in the near future should be lower than in the recent past. Such behavior by itself does not represent a break from past processes of setting wages; empirical wage equations have long suggested that recession and declining price inflation would have such an effect.

Although the concessions have been confined thus far to distressed industries, it might be hypothesized that they would have "spillover" effects on wages elsewhere. Such spillovers could produce short-term wage settlements below what standard wage equations would predict. Or it might even be argued that recent concessions will prove to represent fundamental changes in wage-determination processes for the longer run, particularly changes that would make wage inflation more sensitive to real business cycle conditions.

In this paper I address three questions. First, is the current episode of union wage concessions unprecedented? The answer turns out to be 
Table 1. Wage Increases and Unionization, 1953-76

Percent

\begin{tabular}{ccc}
\hline Period & $\begin{array}{c}\text { Industries with } \\
\text { above-average } \\
\text { unionization rates }\end{array}$ & $\begin{array}{c}\text { Industries with } \\
\text { below-average } \\
\text { unionization rates }^{\mathrm{b}}\end{array}$ \\
\hline $1953-58$ & 4.4 & 3.9 \\
$1958-64$ & 3.3 & 3.2 \\
$1964-68$ & 4.4 & 4.6 \\
$1968-71$ & 6.6 & 6.1 \\
$1971-73$ & 7.8 & 6.1 \\
$1973-76$ & 9.0 & 8.0 \\
$1953-76$ & 5.3 & 4.8 \\
\hline
\end{tabular}

Source: Daniel J. B. Mitchell, Unions, Wages, and Inflation (Brookings Institution, 1980), p. 40.

a. Wage increase is annual change in average hourly earnings.

b. Unionization rates are based on the contract file of the U.S. Bureau of Labor Statistics.

negative. Similar episodes have occurred in the past, and these experiences suggest that permanent and fundamental changes in wage-determination processes are unlikely to occur in the absence of external intervention. Second, could the government intervene during the current concession episode to make useful reforms in wage-setting processes that would increase the responsiveness of wage adjustments to the business cycle? It is suggested that the adoption of "gain sharing" plans (such as profit sharing) in some current concession situations is a tendency that the government might encourage. Third, could possible spillovers from the current union concessions lead to widespread moderation in wage change throughout the economy? Traditional channels of wage imitation are outlined in an effort to answer this. However, preliminary evidence suggests that spillover outside the traditional channels had not occurred as of early 1982.

\section{Long-Run Influences on Union Contract Concessions}

Tables 1 and 2 report the effects of unionization on wage trends since the mid-1950s. Until the mid-1970s, the U.S. Bureau of Labor Statistics did not provide separate data on union and nonunion wages. Hence table 1 relies on a division of the work force into industries with above-average 
Table 2. Wage Increases and Unionization, 1976-81 ${ }^{\text {a }}$

Percent

\begin{tabular}{ccc}
\hline Year & $\begin{array}{c}\text { Union } \\
\text { sector }\end{array}$ & $\begin{array}{c}\text { Nonunion } \\
\text { sector }\end{array}$ \\
\hline 1976 & 8.1 & 6.8 \\
1977 & 7.6 & 6.6 \\
1978 & 8.0 & 7.6 \\
1979 & 9.0 & 8.5 \\
1980 & 10.9 & 8.0 \\
1981 & 9.6 & 8.5 \\
\hline
\end{tabular}

Source: Current Wage Developments, various issues.

a. Wage increase is annual change in the employment cost index. Data are on a December to December basis.

and below-average unionization rates to estimate differences between union and nonunion wage increases. The wage differential widened from the end of the Korean War until the mid-1970s. For the 1976-81 period, direct data on union and nonunion wage trends are available and appear in table 2 . These show a continued widening of the union-nonunion wage gap.

The expanding union-nonunion wage differential could help explain a number of phenomena affecting unions. These include the relative shrinkage in the size of the union sector and the increasing hostility to new organization on the part of management about which unions have complained in recent years. From the perspective of wage determination, however, the widening gap may have created economic forces requiring readjustments of the wage structure. Where the union wage premium has widened, competitive pressures from the nonunion or foreign sectors have presumably grown. Such pressures originating in product markets will eventually reduce job opportunities for union workers and create pressures for wage concessions.

\section{Short-Run Developments}

Wage equations suggest that a widening union-nonunion wage gap would have a modest impact on wage inflation. My earlier Brookings study indicates that the widening of the gap reflected in table 2 would subtract about 0.5 to 0.8 percentage point from the rate of union wage 
change by $1982 .{ }^{1}$ However, such an effect has not been widespread. The union sector appears to have become segmented, with dramatic concessions occurring in some industries while other wage settlements seem largely unaffected.

Whether a given contract settlement is a concession is obviously subjective. It might be argued that a union that negotiates a wage increase of 7 percent when 10 percent has been expected has made a concession. The difficulty of estimating an expected wage adjustment for individual settlements, however, precludes the use of such a broad definition of concession for analytical purposes. Instead, a narrowly defined list of concessions was drawn for the period beginning in 1979 and ending in early 1982 from published sources such as Current Wage Developments.

Concessions were defined as including wage cuts, wage freezes, premature renegotiations of existing contracts (the termination of an existing agreement before the official expiration date and its replacement with a new contract providing less favorable terms to workers), an easing of work-rule restrictions in a manner likely to decrease employer costs, and a miscellaneous category of other notable breaks from past practice. Forty-six such situations were identified. ${ }^{2}$ Of these, twenty-one were wage cuts and thirteen were wage freezes. In eleven cases, work rules were relaxed. At least twenty-six of the concessions involved premature renegotiations of unexpired contracts. The industries covered by concessions included newspapers and printing, supermarkets, railroads, tires and rubber, automobiles, automotive parts, steel, trucking, airlines, farm machinery, construction, meat packing, ship building, and paper manufacturing. Although a precise count of the number of workers covered by the concessions is not possible, the number would certainly

1. In a previous Brookings study I included a relative wage variable in wage-change equations for various union contracts. The variable was defined as the ratio of the wage in the industry to the average wage in the private, nonfarm economy. The coefficient was invariably negative, suggesting that wages that rise relative to the average tend to exhibit slower future wage growth. The union wage figures of table 2 suggest a widening of the ratio of about 4.3 percent from December 1975 to December 1981 . Multiplying 0.043 by the $R E L$ coefficients (relative earnings status of the industry before the effective date of the contract) in equations 3 and 4 of table 4-7 in Daniel J. B. Mitchell, Unions, Wages, and Inflation (Brookings Institution, 1980), produces the results described in the text. See also Mitchell, "Union Wage Determination: Policy Implications and Outlook," BPEA, 1978:3, p. 556.

2. A list will be provided by the author on request. 
be less than two million, with the largest groups in the automobile and intercity trucking industries.

It was clear from the descriptions of the forty-six instances of concessions that imminent closing of plants, layoffs, and bankruptcies motivated the agreements. In some cases, when management's demands for concessions were rejected, steps were taken to cut back production and employment. These steps sometimes produced worker acquiescence. In a number of instances, the wage concessions were "sweetened" by implementation of a profit-sharing plan whereby workers would gain if the economic health of the employer was eventually restored. Instances of worker ownership or partial ownership were also reported. In some cases, wage increases were suspended or a portion of current wages was "put aside." This may have been intended by the union to indicate that the wage rates were merely in some ill-defined limbo from which they would emerge in better times. Several settlements provided explicit guarantees of job security or agreements for advance warning of future layoffs.

Some of the employers affected, such as automobile and tire manufacturers, were particularly hurt by the poor economic performance of their industries since 1979. Others, such as the newspapers and meat packing industries, may have been victims of long-run trends that were, at most, aggravated by the weakness in the general economy. In three cases, Chrysler Corporation, Consolidated Rail Corporation (Conrail), and the Chicago-Milwaukee Railroad, the federal government was involved in imposing the concessions. Competition arising from deregulation adversely affected employers in the trucking and airlines industries. And import competition has grown in several segments of manufacturing.

Along with the concessions there has been much talk about worker enlistment by management in improving productivity, worker participation in management, and the quality of working life. For example, a union representative was placed on the board of directors of Chrysler; similar moves were initiated at American Motors Corporation but were stymied by antitrust problems. A peculiar blend of cooperative rhetoric and toughness has emanated from management. Management has been able to take a hard line_- "take a cut or we close the plant." But there has also been discussion in industrial relations circles of the need to end the "adversary relationship." 
Experience has varied when the issues of concessions have arisen. In some cases workers vetoed concessions and were laid off. In other cases, the desires of local workers were not honored by national unions concerned with maintaining the integrity of industry-wide contracts. And despite the concessions that did occur, there was a substantial increase in unemployment among union workers after 1979.

The Bureau of Labor Statistics reports that in 1981 about 67,000 workers who negotiated in 1981 received first-year wage cuts or freezes. At the same time, roughly 160,000 apparel workers experienced unscheduled reopenings-justified on the grounds of unanticipated inflationthat led to extra pay increases. The net effect of all these developments had little overall impact during 1981 when the average wage adjustment negotiated, including those for workers experiencing freezes and cuts, was more than 10 percent. $^{3}$

\section{Concessions in the Trucking and Automobile Industries}

Wage concessions in the intercity trucking industry and at the Ford Motor Company and General Motors Corporation in the automobile industry have received by far the greatest amount of public attention. Nominally, the new International Brotherhood of Teamsters' National Master Freight Agreement covered about 300,000 workers, although large layoffs in the trucking industry make the estimate uncertain. The new 1982 contract was officially negotiated early; it was concluded two months before the old contract would have expired on March 31. In principle, the union refused to reopen the previous agreement, but since the new one superseded the old, the result was equivalent to a premature reopening. The Teamsters' concessions were negotiated against a background of federal deregulation of the trucking industry, a structural change that permitted entry of nonunion competition. During the final year of the old agreement it was widely reported that many trucking

3. Some workers experiencing wage cuts or freezes may have received escalator payments; such payments are not included in Bureau of Labor Statistics estimates of negotiated adjustments. Excluding escalator payments, the average first-year wage adjustment was 10.1 percent in 1981 for major contracts. See "Major Collective Bargaining Agreements in the Private Sector, 1981," U.S. Bureau of Labor Statistics News, USDL 82-32, January 29, 1982. 
employers were paying less than contractual wages with apparent acquiescence from local Teamsters unions.

Under the new agreement no general wage increases are provided. The escalator clause is continued at the previous formula of one cent for each increase of 0.3 point in the consumer price index. This formula provides a little more than 70 percent protection of the real wage in early 1982 , so that the contract involves a real wage decrease. Moreover, the frequency of escalator payments is reduced from semiannual to annual and provision is made for diversion of increases arising from the escalator to go into various fringe benefits. Such diversions, which are left to the discretion of a labor-management committee, could in theory eliminate all wage increases coming from the escalator, except for a specified component of the initial increment due on April 1, 1982. Work-rule restrictions were relaxed to permit greater employer flexibility in arranging pickups and deliveries. In return for these concessions, employers in the trucking industry agreed not to operate nonunion subsidiaries. The new contract expires March 31, 1985, but contains a provision for reopening a year before expiration if the economic condition of the industry substantially improves or deteriorates.

The 1982 concessions in the automobile industry really had their beginning in 1979 when Chrysler found itself in serious economic difficulties. Chrysler was permitted to deviate from the Ford and General Motors contracts signed in the fall of 1979 , primarily by delaying certain wage adjustments and reducing pension contributions. A second round of concessions was required as the price for federal loan guarantees in early 1980. However, Chrysler workers received a stock-ownership plan under the enabling legislation. Finally, in January 1981, as the company's position continued to deteriorate, a third round of concessions froze wages and eliminated past and future escalator adjustments. A profitsharing plan was established in exchange for these concessions. Because Ford and General Motors continued to operate under the traditional escalator formula of 3 percent plus, a considerable wage gap began to develop between Chrysler and its major competitors. By the time the United Automobile Workers (UAW) reached concession agreements with Ford and General Motors in early 1982, Chrysler's straight-time wage was probably 20 to 25 percent below the wage at the other companies.

About 700,000 workers in the automobile industry, many of them on 
layoff, were estimated to be covered by the "big three" concession agreements. The Ford and General Motors settlements, which superseded the existing contract and extended to September 1984, eliminated the 3 percent annual improvement factor and froze wages by delaying escalator payments. Both automobile agreements, following the Chrysler example, included profit-sharing plans. And both addressed job security concerns of the union by providing certain income guarantees for workers with seniority and various assurances with regard to future plant closings. Both agreements provide for early reopening in the event that automobile sales return to the high levels achieved in the late 1970 s.

Because their escalator is more generous than the Teamsters' formula (over 90 percent protection), and because the diversion of escalator money will be less in the automobile industry than in the trucking industry, real wages will decline less for Ford and General Motors workers than for truckers. However, certain similarities between the automobile and trucking concessions are noteworthy. First, in the absence of declines in the CPI, both concessions eliminate the possibility of real wage improvements. Second, both attempt to retain the principle of escalation and of multiyear agreements. Third, both provide for reopening if conditions improve, a signal that the concessions should be regarded as temporary, even if the reopener is not triggered.

\section{Some Historical Perspectives}

The concessions made by unions since 1979 are unusual enough to attract media attention, but they are by no means unprecedented. Groups of concessions, over a relatively short period, have been known to occur in the past. Obviously during the Great Depression wage cuts were common. It is more useful, however, to look to the post-World War II period since modern institutions of collective bargaining had developed by that time. Two postwar episodes can be identified, one occurring right after the Korean War and the other in the late 1950s and early $1960 \mathrm{~s} .{ }^{4}$

4. Information on wage settlements described below in the text was drawn from such sources as Current Wage Developments, Monthly Labor Review, and Daily Labor Report. An earlier version of this paper, available from the author, contains detailed references. 
THE POST-KOREAN WAR EPISODE

Immediately after the Korean War, union wages were cut in the garment and textile industries. These cuts occurred during a period of recession and slight decreases in consumer prices. Often they were not readily accepted and were preceded by strikes or imposed by arbitrators. Although escalator clauses today often do not provide for wage decreases in response to price decreases, some of those existing in the early $1950 \mathrm{~s}$ were symmetrical. As a result, some unionized workers did experience reductions in that part of their wage arising from cost-of-living allowances during and after the Korean War. The fact that escalators could no longer be counted on to raise wages may have contributed to their reduced popularity. However, the common practice of separating the basic wage and the cost-of-living allowance tended to cushion the psychological impact; the official wage was not cut, just the allowance.

Other developments in the post-Korean War period are reminiscent of recent events. In some cases, notably at Studebaker Corporation, workers rejected wage cuts negotiated by their unions. Sometimes such rejections were followed by plant closings. In other cases, concessions were more artfully packaged-as at Kaiser-Willys Incorporated-and were accepted. Although there were often confrontations over concessions, there were also instances of labor-management cooperation. At times, employees purchased stock in the companies, and unions provided financial assistance. Unions and management in distressed industries issued common appeals for governmental regulations that would increase employment. The frequency of strikes declined to a six-year low. In some instances unions permitted deviations from previous patternsetting arrangements to accommodate individual employers.

The 1953-54 recession also produced demands for job-security arrangements. In some cases unions were able to obtain only vague assurances of continued production. At the major automobile firms and in other industries more dramatic concessions were obtained from management. For many years there had been talk of a guaranteed annual wage for blue collar workers that would shield their incomes from the ups and down of production. Proposals for employment guarantees go back at least to the 1920s, and a scattering of such plans existed before World War II. In 1955 a breakthrough occurred in automobiles and other industries when the modern supplemental unemployment benefits plan 
(SUB) was inaugurated. The income guarantees achieved during the 1982 concessions at Ford and General Motors are in effect "superSUBs," which can be seen as extensions of these earlier plans.

\section{THE PERIOD OF "MANAGEMENT HARDENING"}

Table 1 indicates that the union-nonunion wage differential widened during 1953-58. But by the early 1960s there was talk in industrial relations circles of a "hardening" (taking a "hard line") on the management side. A prolonged and bitter strike occurred in the steel industry in 1959. Steel management conducted a major public relations program aimed at projecting an image of itself as the victim of restrictive work rules. A bitter strike also occurred in the late 1950s in the electrical equipment industry. Management in the automobile industry began to increase its interfirm cooperation during negotiations. In the newspaper publishing, airline, and railroad industries, "mutual assistance pacts" and strike insurance plans were established to provide aid to employers on strike. These developments occurred against a background of two recessions, one in 1957-58 and one in 1960-61.

Table 1 suggests that union and nonunion pay rose at comparable rates during 1958-64 in contrast to the earlier widening of the wage gap. Wage reductions were rare in the early 1960s, but decisions not to increase union wages were quite common. More than 27 percent of union workers in manufacturing in 1962 received no general increases of any type. Strike frequency declined. It might be noted that it was in the early 1960s that econometric studies by Perry and others found evidence of below-normal wage changes, especially in "visible" industries. ${ }^{5}$ These were interpreted as indications of success of the wage-price guideposts program. An alternative explanation could be that there was a management hardening, provoked perhaps by union wage gains in the late 1950s, and that this trend persisted into the 1960s. Or perhaps the guideposts reinforced management's stance.

In the case of steel, there is evidence of a traumatizing effect of the 1959 strike. Labor and management believed that the strike had induced

5. See George L. Perry, "Wages and the Guideposts," American Economic Review, vol. 57 (September 1967), pp. 897-904. For a review of such studies, see John Sheahan, The Wage-Price Guideposts (Brookings Institution, 1967), pp. 83-92. The estimate of workers receiving nogeneral increase is drawn from Ruth W. Benny, "Wage Developments in Manufacturing," Monthly Labor Review, vol. 88 (October 1965), p. 1185. 
domestic steel consumers to sample foreign suppliers, leading to some permanent loss of markets. A considerable effort was made at promoting labor-management cooperation during the early 1960 s by both sides. Most notably, a human relations committee was established that dealt with areas of mutual concern and negotiated a series of moderate oneyear agreements. During this period the escalator clause was dropped from the steel wage agreement.

Other instances of labor-management cooperation appeared during the early 1960s, notably in West Coast longshoring, and in Kaiser Steel Corporation and Armour and Company. On the West Coast, the International Longshoremen's and Warehousemen's Union and the Pacific Maritime Association engaged in what was commonly referred to as productivity bargaining. The resulting "mechanization and modernization" agreement, which lasted into the 1970s, provided for acceptance by the union of various changes in work rules to permit automation and handling of containerized freight. In exchange, employers provided various benefits and job guarantees. The agreement, first reached in 1960 , yielded large increases in productivity and cost savings.

The Kaiser "long-range sharing plan" arose out of the steel strike in 1959 after Kaiser broke with other steel firms and reached a separate settlement with the United Steelworkers. A committee was established to consider issues such as technical change, worker displacement, and other matters of concern to both parties. In late 1962 the committee announced its new plan for workers to receive a share of productivity gains, calculated by a formula, and various employment and retraining guarantees. The Armour Automation Committee was established in the meat packing industry in 1959. The committee provided a forum for the study of employment problems caused by plant closings and technical change and was credited with providing retraining and placement services for displaced workers. Generally there was much talk and discussion in the early 1960s about automation, structural unemployment, and related issues. In some ways the concern about automation in the early 1960s can be compared to the recent apprehension about plant closings, "robotics," and keeping pace with Japanese technology.

\section{LESSONS FROM THE PAST}

It is clear that the current atmosphere of concessions has precedents in the past. Previous episodes have usually occurred during a period of 
economic slack and a threat to job security. A paradoxical mixture of management aggressiveness and experiments in labor-management cooperation seems to develop in such periods. But what permanent effects can be expected?

The main lesson from the two past episodes of union concessions is that the dramatic changes are largely transitory. For example, the shift to a one-year contract cycle in the steel industry and the abandonment of escalation lasted only a few years. Such a shift had the potential of making wages more sensitive to short-term real economic fluctuations. It also carried the risk of more frequent exposure to strikes. In the era of cooperation that existed in the early 1960s, labor and management in the steel industry could live with this risk. Over time, however, the cooperative spirit eroded. The incumbent president of the Steelworkers was voted out partly on the grounds that he had been too cooperative with management. As cooperation became less certain, the logic of the multiyear escalated contract reasserted itself. In other industries similar developments occurred. The three pioneering plans at Armour, Kaiser Steel, and in West Coast longshoring described above ceased to exist. As employment expanded in the late 1960s, the sense of crisis that brought those plans into existence evaporated.

\section{Wage Outcomes of the 1973-75 Recession}

Both the post-Korean War period and the period from the late 1950s to early 1960s produced concessions against a background of economic slack. But not all recessions have produced such dramatic effects. In particular, the severe recession that began in late 1973 did not produce concessions in the large union settlements that receive prominent press attention. The fact that concessions were not widely observed at that time may have contributed to the impression that union wages are wholly insulated from market pressures.

It is argued below that wage experience of the major union contracts during the 1973-75 recession is largely explained by accidents of timing with regard to expiration and renegotiation of long-term contracts, the use of escalation during a period of oil-shock inflation, and the failure of the 1973-75 recession to produce widespread threats of permanent job loss to senior workers. While the period of recent contract concessions 
beginning in 1979 opened with certain similarities to the 1973-75 experience, the primary difference between the two periods was the greater threat to senior workers in the recent period.

It should be noted that there were a few instances of concessions and shifts in wage behavior during the 1973-75 recession and its aftermath. In the newspaper industry contracts were reached between printers and owners in New York City and Washington, D.C., which provided for an end to restrictive work rules in exchange for "lifetime" job guarantees and early retirement bonuses. Similar arrangements were later worked out for commercial printers. Union wage settlements in construction soared after federal wage controls were lifted in early 1974, but scattered wage freezes, wage reductions, and work-rule modifications were subsequently reported. Wage reductions were also reported in the airline industry. As in the current period, management was sometimes able to win concessions by tying them to the introduction of profit sharing.

Probably the most dramatic shifts in the behavior of union wages came in the public sector. In the late 1960s and early 1970s a significant body of opinion held that the public could not "take" a strike of government employees and that, therefore, unions in the public sector could be expected to negotiate exceptionally large wage settlements. In some government sectors wages did rise more rapidly than in private employment during the late 1960s. However, by the mid-1970s, the New York City fiscal crisis provoked a series of wage freezes and other concessions. It has been argued that New York City's problems had a demonstration effect on wage settlements in other municipalities. ${ }^{6}$

The general slump in productivity improvement after 1973 also may have influenced some major contract settlements. It is true that union wages were more insulated from the productivity decline than nonunion wages. But there was some erosion in the wage increase formula of the "3 percent plus escalator" originally enshrined in the 1948 General Motors contract. Since escalators generally provide less than 100 percent protection against inflation, high rates of price increase erode the real value of the 3 percent factor. Beginning in the automobile industry in 1973, and then in automotive parts, metals, apparel, and other industries, escalator "diversions" became commonplace. Typically these consisted

6. For example, see Harry C. Katz, "Municipal Pay Determination: The Case of San Francisco," Industrial Relations, vol. 18 (Winter 1979), pp. 55-56. 
of putting some part of the wage increase specified by the escalator into the financing of some benefit, often pension improvements. In the 1979 automobile settlements the 3 percent factor was further eroded by applying it to the base wage excluding the cost-of-living allowance.

It is true, nonetheless, that during the 1973-75 recession wage concessions were less visible than has been the case recently. Table 3 tracks a selected group of major union negotiations during 1973-81. The actual wage increases under settlements reached during 1973-78 are given. Thereafter, 10 percent price inflation is assumed for estimating the increases achieved under escalated contracts. Settlements with relatively low rates of increase in 1973 (electrical, petroleum, tires, and trucking) were negotiated during the first half of the year. Although inflation had begun accelerating from the low point reached in 1972, the rate of inflation that had been achieved earlier may have moderated these initial settlements. In addition, wage and price controls were still in effect.

The larger settlements reached later in 1973 (meat packing and automobile industries) were concluded in a period when it was clear that inflation was accelerating and wage-price controls were being lifted. In 1974, inflation as measured by the CPI reached a then post-World War II peak, and wage-price controls were terminated. The 1974 settlements reflect these inflationary pressures.

It is evident from table 3 that the existence of an escalator clause in contracts negotiated in 1973-74 made a large difference in the wage increase actually received. The 1973 contracts providing the lowest rates of wage increase either had no escalator (petroleum refining, tires) or had escalators with "caps" that prevented inflation above a specified level from influencing wage adjustments (electrical equipment and trucking). In 1974 petroleum proved an exception to this generalization. Although the nonescalated contract did not expire until 1975 and contained no reopener clause, the oil companies agreed to an unscheduled 6 percent wage increase on top of what the contract specified for the second year. At the time, the substantial boost in OPEC prices had dramatically raised oil industry profits; gasoline shortages had occurred; and the industry was not in a position to play the hard-hearted employer.

The importance of escalator adjustments to wages in the union sector is clear from table 4. Since 1973 one-fifth to one-third of the annual wage adjustment experienced in the major union sector (private agreements 


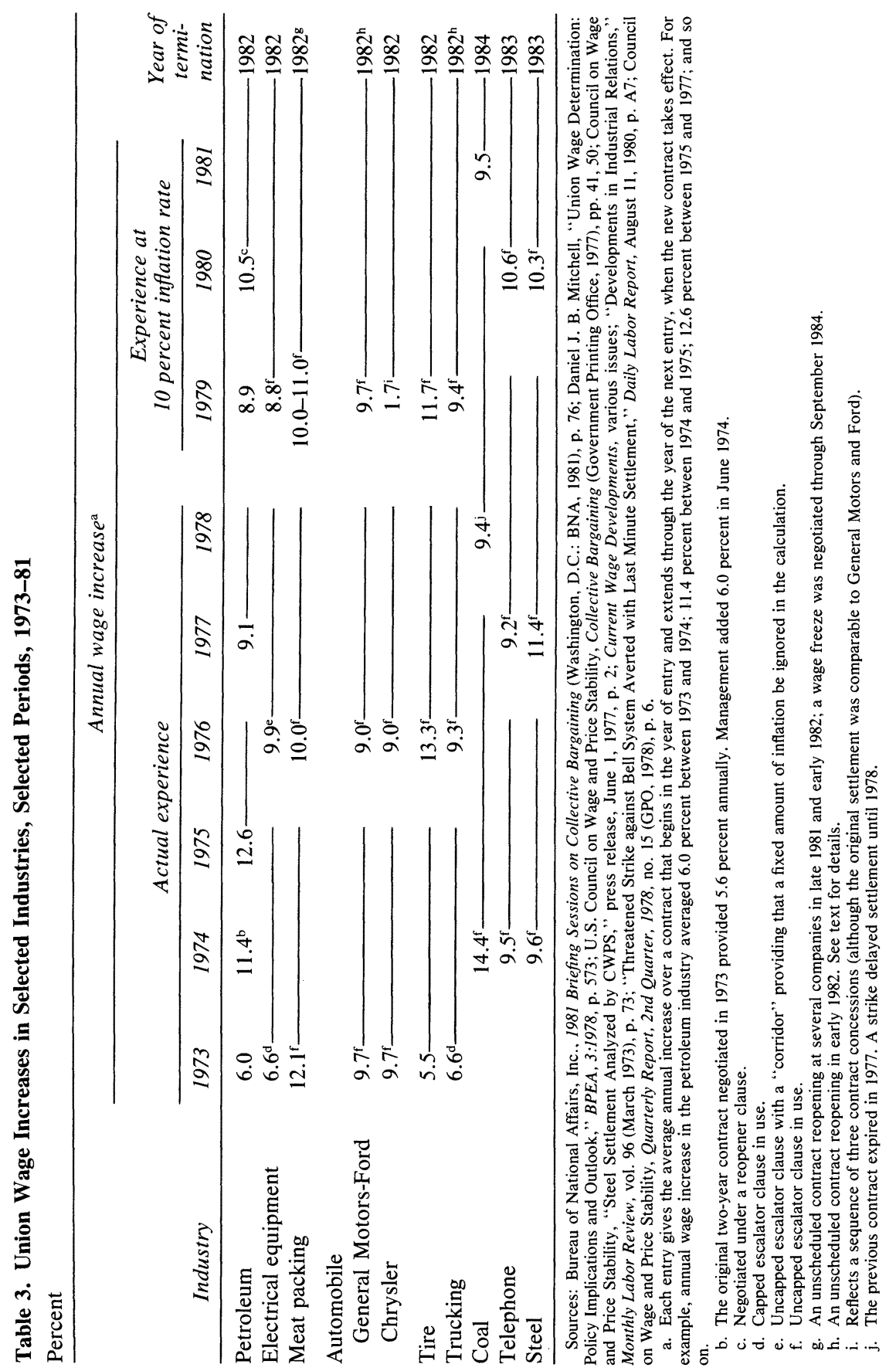


Table 4. Escalation and Wage Increases in Major Unions, 1972-82 ${ }^{\text {a }}$

Percent

\begin{tabular}{|c|c|c|c|c|c|c|}
\hline \multirow[b]{2}{*}{ Year } & \multicolumn{2}{|c|}{$\begin{array}{l}\text { Effective hourly } \\
\text { wage change }\end{array}$} & \multicolumn{2}{|c|}{$\begin{array}{l}\text { Life-of-contract annual } \\
\text { wage change in major } \\
\text { contracts expiring } \\
\text { in year shown }\end{array}$} & \multirow[b]{2}{*}{$\begin{array}{l}\text { Annual } \\
\text { change in } \\
\text { consumer } \\
\text { price index }\end{array}$} & \multirow{2}{*}{$\begin{array}{l}\text { Proportion } \\
\text { of workers } \\
\text { covered by } \\
\text { escalators } \\
\text { at begin- } \\
\text { ning of } \\
\text { year }\end{array}$} \\
\hline & Total & $\begin{array}{l}\text { Proportion } \\
\quad \text { due to } \\
\text { escalator } \\
\text { provisions }\end{array}$ & Escalated $^{\mathrm{b}}$ & $\begin{array}{c}\text { Not } \\
\text { escalated }\end{array}$ & & \\
\hline 1972 & 6.6 & 10.6 & n.a. & n.a. & 3.4 & $41^{\circ}$ \\
\hline 1973 & 7.0 & 18.6 & n.a. & n.a. & 8.9 & 39 \\
\hline 1974 & 9.4 & 20.2 & n.a. & n.a. & 12.3 & 39 \\
\hline 1975 & 8.7 & 25.3 & n.a. & n.a. & 7.1 & 51 \\
\hline 1976 & 8.1 & 19.8 & 7.8 & 6.6 & 4.9 & 59 \\
\hline 1977 & 8.0 & 21.3 & 8.8 & 8.6 & 6.6 & 61 \\
\hline 1978 & 8.2 & 29.3 & 8.1 & 7.2 & 9.1 & 60 \\
\hline 1979 & 9.1 & 34.1 & 8.4 & 7.3 & 13.4 & 59 \\
\hline 1980 & 9.9 & 28.3 & 8.4 & 7.5 & 12.5 & 58 \\
\hline 1981 & 9.1 & 30.8 & 8.6 & 7.7 & 8.7 & 58 \\
\hline 1982 & n.a. & n.a. & 8.8 & 7.4 & n.a. & 57 \\
\hline
\end{tabular}

Sources: Monthly Labor Review, reviews of bargaining calendar and deferred increases, various issues; Current Wage Developments, various issues.

n.a. Not available.

a. Major private agreements.

b. Underestimated. See text for details.

c. CPI for urban wage earners and clerical workers on a December to December basis.

covering 1,000 or more workers) has come from escalators. This proportion tends to rise and fall with the rate of CPI inflation and with the percentage of workers covered by escalator clauses, a percentage that increased dramatically during the contract negotiations of 1974 and 1975.

Beginning in 1976 the Bureau of Labor Statistics has made available tabulations of the wage increases experienced under expiring major union agreements by escalator status. The estimates understate the wage increases experienced under escalated contracts, since the bureau makes its calculations just before the year of expiration and does not impute further CPI increases for that year. Nevertheless, table 4 indicates that wage increases under escalated contracts have consistently outpaced those under nonescalated agreements for contracts expiring in each year since 1976 and by a substantial amount in all years but one. During this period the ratio of escalated to nonescalated wage rates appears to have risen significantly. 
Apart from the effects of escalation, accidents of timing conditioned the outcomes of wage settlements beginning in 1973. By the time the recession of 1973-75 got under way in November, all the 1973 contracts shown in table 3 were settled or largely concluded. The only signs of a concession in the 1973 contracts were certain less favorable terms negotiated for workers at the electrical equipment division of General Motors (Delco Electronics and Frigidaire), where wages based on those in the automobile industry had reportedly gotten out of line with those of competing electrical firms.

Even in early 1974 there was still a good deal of uncertainty about what was happening to the economy. The oil embargo and price controls together produced gasoline shortages that particularly affected industries such as automobiles and mobile homes. Many observers confused the beginnings of a recession with the transitory effects of a gasoline supply problem.

Steel was the only industry that negotiated in 1974 and that might have been expected to be recession prone. Normally the steel negotiations would have taken place over the summer because the contracts expire on August 1. However, the parties to the basic steel agreement, ever mindful of the traumatic steel strike of 1959, created the experimental negotiating agreement (ENA) in March 1973. ENA prohibited national strikes and created an arbitration panel to make a binding settlement if the parties had not reached one of their own by April 15, 1974. A settlement was reached privately before the self-imposed deadline. In exchange for its no-strike pledge, the union had received a guarantee that the 1974 agreement would contain at least an increase of 3 percent plus the escalator for each of the next three years. Thus the steel industry's basic wage formula for 1974 was locked in by early 1973.

Table 5 shows the cyclical responses of output and employment in the nine industries whose contracts were reviewed in table 3. During 1973-75, output and employment declined sharply in electrical equipment, automobiles, tires, trucking, and steel. Employment in meat packing declined slightly; its figures are distorted by the meat shortage of 1973. Output declined in petroleum refining, but the oil industry was in no position to claim poverty, either in 1974 or 1975 . Output and employment in coal mining increased in response to the rise in energy prices. Hence there was no reason to expect a restrained wage settlement in that industry. Finally, although employment fell in telephone com- 
Table 5. Change in Output and Employment of Production and Nonsupervisory Workers, Selected Industries and Periods, 1973-80a

Percent

\begin{tabular}{|c|c|c|c|c|}
\hline Industry and category & $1973-75$ & $1975-76$ & $1975-79$ & $1979-80$ \\
\hline \multicolumn{5}{|l|}{ Petroleum } \\
\hline Output & $-3.4^{b}$ & 7.6 & 16.0 & -7.6 \\
\hline Employment & $2.3^{\mathrm{b}}$ & 4.1 & 11.8 & -11.0 \\
\hline \multicolumn{5}{|l|}{ Electrical equipment } \\
\hline Output & -18.6 & 15.6 & 50.2 & -1.3 \\
\hline Employment & -18.8 & 6.3 & 27.2 & -3.7 \\
\hline \multicolumn{5}{|l|}{ Meat packing } \\
\hline Output & $5.0^{\mathrm{c}}$ & 7.9 & 2.8 & 3.7 \\
\hline Employment & $-0.8^{\mathrm{c}}$ & 3.0 & 8.5 & -0.2 \\
\hline \multicolumn{5}{|l|}{ Automobile } \\
\hline Output & -24.8 & 27.6 & 42.4 & -25.3 \\
\hline Employment & -20.2 & 13.3 & 26.9 & -27.1 \\
\hline \multicolumn{5}{|l|}{ Tire } \\
\hline Output & -16.4 & $0.7^{\mathrm{d}}$ & $10.7^{\mathrm{e}}$ & -22.9 \\
\hline Employment & -6.5 & $-20.9^{d}$ & 1.9 & -7.6 \\
\hline \multicolumn{5}{|l|}{ Trucking } \\
\hline Output & -19.4 & 15.6 & 36.9 & -18.0 \\
\hline Employment & -7.9 & 4.2 & 22.0 & -5.8 \\
\hline \multicolumn{5}{|l|}{ Coal } \\
\hline Output & 8.0 & 3.2 & 19.9 & 8.0 \\
\hline Employment & 31.6 & 5.4 & 20.8 & -5.1 \\
\hline \multicolumn{5}{|l|}{ Telephone } \\
\hline Output & 11.3 & 7.1 & 44.6 & 9.0 \\
\hline Employment & -3.9 & -1.6 & 4.4 & 0.8 \\
\hline \multicolumn{5}{|l|}{ Steel } \\
\hline Output & -21.9 & 9.5 & 18.2 & -18.4 \\
\hline Employment & -11.7 & 0.6 & 5.4 & -12.3 \\
\hline
\end{tabular}

Sources: All output data except that for the telephone and trucking industries are from Survey of Current Business, various issues; telephone output is from Bureau of Labor Statistics, Productivity Measures for Selected Industries, 1954-79, Bulletin 2093 (GPO, 1981), p. 183, updated by the BLS; employment data are from BLS, Employment and Earnings, various issues, and they refer to the Standard Industrial Classification codes for the industries shown$291,36,201,371,301,421-3,12,481,331$, respectively.

a. The Federal Reserve Board indexes of industrial production are used as output measures for petroleum, electrical equipment, automobile (motor vehicles and parts), steel (iron and steel), and coal industries. Output of the meat packing and tire industries is total meat and pneumatic casings (automotive) production, respectively. Telephone and trucking output is measured by the index of output for telephone communications and by the index of output of common carriers of general freight, respectively.

b. Influenced by oil embargo and shortages.

c. Influenced by meat shortage.

d. Influenced by strike.

e. The 1979 data omit the tire industry for motorcycles and mobile homes, producing an underestimate. 
munications, output rose, reflecting strong secular productivity performance.

Thus the story of the impact of the 1973-75 recession (or lack thereof) on major union wage settlements is partly one of timing and partly the surge in price inflation and its wage impact through escalation. Although employment and output fell sharply in many industries, most settlements came too early to be affected. Those that came later (coal, petroleum under the unscheduled 1974 reopener and in 1975, and the telephone industry) were not hurt by the recession. However, even though the early contracts were "wrapped up" before the recession began, why were these contracts not reopened in the face of the steep recession, as contracts have been recently?

There is a long history in labor economics of attempts to model union wage setting. Many of these models basically picture the union as a labor-supplying firm that faces a demand curve (the derived demand for labor) and that maximizes some goal under that constraint. Such models are misleading because they suggest that a "marginalist" approach well describes union behavior. The union is pictured as facing a wageemployment trade-off (the downward-sloping demand curve for labor) and as making incremental adjustments to obtain the optimum mix of the two "goods," wage rate and employment.

An obvious issue raised by a marginalist approach is the degree to which a wage-employment trade-off exists, especially in the short run. If the elasticity of labor demand is low, senior workers would have to sacrifice a lot in wages to produce small gains in job security for their junior counterparts. Estimates of elasticities of labor demand are not available, although some research suggests that unions face inelastic demand curves. Examination of the ratio of labor costs to total costs can provide an indication of the degree of demand elasticity $;^{7}$ such estimates are provided below for 1972, the year preceding the 1973-75 recession.

7. For evidence on labor-demand elasticities facing unions, see Richard B. Freeman and James L. Medoff, "Substitution Between Production Labor and Other Inputs in Unionized and Non-Unionized Manufacturing," Discussion Paper 581 (Harvard University, Institute of Economic Research, October 1977). Alfred Marshall pointed out that the elasticity of labor demand will tend to be low when the ratio of labor costs to total costs is low. This influence can be overcome by substitution effects, but such effects are ruled out by assumption in the text. See J. R. Hicks, The Theory of Wages, 2d ed. (St. Martin's Press, 1963), pp. 241-46. 


$\quad$ Industry
Petroleum
Electrical equipment
Meat packing
Automobile
Tire
Trucking
Coal mining
Telephone
Steel

Compensation of employees
per dollar of output
${\text { (percent })^{8}}^{7}$
46
11
25
25
44
45
51
33

Assuming no substitution of other factors for labor in the short run, and assuming labor costs pass through to prices, the percentage reduction in price that could result from a reduction in labor costs is simply the ratio of labor costs to total cost multiplied by the percentage reduction in labor cost. That is, a labor cost ratio of 20 percent suggests that a 10 percent wage cut could translate into a 2 percent price reduction. The output effect can be estimated as the product elasticity of demand for the employer's output multiplied by the price reduction.

The list above shows that the labor cost ratio was 33 percent or less in the steel, petroleum, automobile, meat packing, and tire industries. Relatively high ratios appear in the telephone and coal mining industries, in which there was increased output during the 1973-75 recession, and in trucking, in which regulation then held down nonunion competition. Only in electrical equipment was there a relatively high ratio (still below 50 percent) and no insulation from recession. Generally if unions were

8. For the electrical equipment, automobile, and coal mining industries the figures shown are employee compensation per dollar of industry output (excluding intraindustry consumption) for input-output industries with SIC code numbers 53 through 58, 59, and 7, respectively. The figure for trucking is compensation per dollar of operating revenue for class 1 motor carriers. The telephone estimate refers to wages and salaries of the Bell System divided by operating revenue; this ratio was then multiplied by the ratio of compensation to wages and salaries from the national income accounts for telephone and telegraph. For the petroleum, meat packing, tire, and steel industries the ratio of payroll to shipments (for SIC codes 291, 301, and 331) was multiplied by the ratio of compensation to wage and salary for the corresponding two-digit industry in the national income accounts. To adjust for intraindustry shipments, the ratio of such shipments to total industry output was calculated from the 1972 input-output "use" table for industries with SIC codes $31.01,14.0101$ through $14.0104,32.01$, and 37.0101 through 37.0105. 
sensitive to marginal wage-employment trade-offs, they might have found few gains at the margin from wage concessions due to low elasticities in the demand for labor.

In principle unions might have raised the effective elasticities to unity by making combination deals involving wage concessions and employment guarantees. As a first approximation, an employer might be indifferent between a 10 percent layoff and a 10 percent wage cut (below what wages would otherwise be). Either adjustment cuts payroll by the same 10 percent. But even assuming that a one-for-one trade-off could be obtained, it might not be acceptable to the union, given its political process.

There is recent recognition in the literature on labor economics that union decisionmaking responds to senior workers who are inframarginal with regard to layoffs, largely due to the seniority systems that they themselves helped to impose. Unless the "median voter's" job is threatened, concessions would simply produce income reductions for the majority in exchange for extra employment for the minority. As is noted below, this political calculus might be altered by changing the incentives for gain-sharing plans. But without such incentives, majority altruism is unlikely to produce wage flexibility.

Thus unless there are imminent threats of bankruptcy or permanent plant closings-crisis situations that threaten senior workers-it is unlikely that union wage behavior will be strongly sensitive to recessions. The 1973-75 recession created job losses, but not a sense that those losses would be permanent unless they were remedied by a wage concession. In 1973 the target automobile company chosen by the UAW to set the wage pattern for the "big three" was Chrysler. Clearly at that time the union did not perceive Chrysler to be a marginal firm whose existence might be threatened by a strike, as was the case in 1979 .

\section{Bargaining after the 1973-75 Recession}

The trough of the 1973-75 recession was reached in early 1975 . Table 5 shows that output rose during 1975-76 in all but one of the industries included in the table. Such output gains translated into employment gains except in the telephone industry, in which the long-term rate of rapid productivity improvement continued, and in the tire industry, in 
which a lengthy strike reduced the annual employment totals. There was every reason for bargainers to believe in 1976 and 1977 that the employment outlook was bright.

Although inflation slowed markedly in 1976, union negotiators had recently weathered an extremely inflationary period. Demands were made in 1976 and 1977 for escalator clauses when none existed and for the removal of caps on escalators that had such provisions. Except for the petroleum workers, who remained on two-year contracts, the demands were met. An escalator was added to the tire contracts (see table 3 ) and the cap was removed in trucking. A cap was also removed in electrical equipment, although the new escalator was qualified by a "corridor."9 Management at General Electric Company, the lead company in the electrical negotiations, apparently decided in 1976 that improved relations with its unions was a matter of priority.

Of the industries in table 5, the only one in which an escalator was dropped from a contract was coal mining. The coal industry has a history of difficult labor relations, and a prolonged strike ensued when its contract expired in 1977, marked by several tentative settlements and rejections during which the fate of the escalator teetered uncertainly. In the eventual settlement in 1978, although the escalator was removed, one component of the wage increase was labeled as cost-of-living adjustment.

The climate during 1976-79 generally favored an acceleration of wage settlements. Employment was rising and price inflation was accelerating. In early 1978 the Carter administration proposed a voluntary price and wage deceleration program. The administration also became convinced-apparently erroneously - that an energy emergency was being created by the coal strike and attempted to obtain a Taft-Hartley injunction. When this attempt failed, the public perceived the administration as having been unable to influence a major settlement, although technically the 1978 settlement did represent a wage deceleration from the previous contract.

9. A corridor in an escalator clause is a provision that a certain amount of inflation will be ignored in calculating the adjustment. In the case of electrical equipment, a corridor added in 1976 provided that the escalator would reflect inflation up to 7 percent a year and above 9 percent a year with no credit for the interval between 7 and 9 percent. See Current Wage Developments, vol. 28 (July 1976), p. 1. 
The administration subsequently announced a more formal program with a 7 percent guideline for wage increases. The evidence on the effect of this program on aggregate price and wage indexes is mixed. It is even more difficult to judge its impact on individual contracts, although some agreements were explicitly tied to the guidelines. There did appear to be an initial impact on the petroleum contracts in early 1979. Although the first-year adjustment exceeded 7 percent, over the contracts' two-year duration the annual increase would have averaged about 7 percent. The parties, however, inserted a reopener clause for the beginning of the second year and raised wages further when the guidelines were liberalized in 1980.

Table 3 shows the annual rate of wage change in the escalated contracts for the period beginning in 1979, assuming a 10 percent annual rate of CPI inflation. Although all settlements exceeded the nominal 7 percent standard (and the 7.5 to 9.5 percent standard developed later for 1980 contracts), many of the contracts met the technical requirements of the guidelines. Under the guidelines program, escalated increases were calculated prospectively under modest inflation assumptions. This procedure was initially adopted to encourage escalation at a time when the administration anticipated a slowdown in inflation. In the case of the Teamsters' contract, the administration also made various rule changes permitting certain components of the settlement to be excluded from the computation. In other cases such as in the automobile industry, the administration found the settlement to be acceptable after a stipulation from the employer not to pass the full cost into prices.

To some extent the period beginning in 1979 resembled the early phases of the 1973-75 episode. A second OPEC shock led to sharp oil price increases. Oil price controls and turmoil in Iran combined to produce a gasoline shortage. This, then, turned American consumers away from large domestically built cars, causing particular distress in the automobile and tire industries. Initially damage was sectoral and might well have been perceived as a temporary aberration.

The tire contracts expired in April. By that time there had been sharp increases in gasoline prices, which might have suggested tough times ahead for the tire industry. If such a situation was foreseen, however, its effect seemed to be a weakening of management. In March, Firestone Tire and Rubber Company announced that it would pull out of the industry's mutual assistance pact that provided aid to employers suffer- 
ing from strikes and promised the United Rubber Workers that it would accept whatever was negotiated with the other companies in return for a no-strike pledge.

As in 1973, the onset of recession came too late to influence several of the 1979 settlements. Its major impact was seen in the Chrysler case, but even the Chrysler outcome was largely dictated by Congress, as the price of loan guarantees, and then by the loan authorities. Two major contracts in 1980 in the telephone and steel industries show little evidence of the recession. In the case of the telephone industry, employment expanded in 1979-80. The Communications Workers, the major union in the industry, noted at the time of the negotiations that the economic outlook was "confused." 10 The steel industry was again negotiating early under the ENA, and the "3-percent-plus-escalator" rule was already embedded in that arrangement. In fact, despite ENA's guarantee, the basic wage increase was less than 3 percent, perhaps a weak sign that the recession was having some impact. Finally, the 1981 coal settlement did show signs of concern about job opportunities and nonunion competition. The rank and file rejected an agreement that would have removed the "tax" imposed on coal purchased for resale by operators-an employer payment used to finance benefits-on the grounds that this would stimulate substitution of nonunion coal. As a result, the tax remained in the contract. Internal dissension in the United Mine Workers of America made other adaptations unlikely.

Although the 1979 bargaining round initially unfolded similarly to the 1973 negotiations, it clearly ended on a different note. Three of the contracts shown in table 3 (for the automobile, trucking, and meat packing industries) did not survive until their official expiration dates. In the tire and steel industries individual companies or plants were given permission in midstream to deviate from the industry pattern. The difference in outcomes between 1973-74 contracts and 1979-80 contracts is attributable to the differential level of economic distress surrounding the two periods. The period of economic slack that began in 1979 is still very much present in 1982 . Senior union workers in adversely affected industries face severe threats to job security in the form of mass layoffs, plant closings, and potential bankruptcies. In contrast, the 1973-75

10. "Bargaining Resolution by CWA's Bell System Bargaining Council," Daily Labor Report, April 15, 1980, p. E1. 
recession was sharp but finite. As the contracts negotiated in 1973 and 1974 moved toward expiration, there were clear signs of recovery. The same could not be said for the contracts negotiated during 1979-80.

\section{Has a Turning Point Been Reached?}

The recent wave of wage concessions and early renegotiations has led to predictions of a turning point in industrial relations. As one observer put it, ". . . we're seeing the beginnings of a whole new collective bargaining process that should make many more companies ultimately capable of competing in their markets." ${ }^{11}$ But before engaging in such speculation, it is important to consider what might be meant by a turning point.

The possibilities can be discussed with reference to equation 1 , which is representative of a large family of empirical wage-change equations that have been estimated during the past two decades:

$$
w=a+b U^{-1}+c p+d D_{c}+e D_{f},
$$

where

$w=$ the annual rate of wage change in the union sector

$U^{-1}=$ the inverse of the unemployment rate (or some other procyclical measure)

$p=$ the rate of price inflation (presumably lagged)

$D_{c}=$ a dummy variable equal to 1 in the current period

$D_{f}=$ a dummy variable equal to 1 in some future period.

Significant dummies could indicate what Perry calls a norm shift. ${ }^{12}$

Various possible outcomes might emerge from the current period of wage concessions. It might simply be the case that $d<0$ and $e=0$, that is, wage change in the current period will be below expected levels. If this is the only effect, wage levels in the indefinite future will be lower, but the process of the future wage change will be indistinguishable from previous experience. On the other hand, it is also possible the $d<0$ and

11. Allen Sinai of Data Resources, Inc., quoted in Tom Redburn, "Economists See Recovery, Then Tailspin," Los Angeles Times, January 19, 1982.

12. George L. Perry, "Inflation in Theory and Practice," BPEA, 1980:1, pp. 207-41. 
$e>0$. Under such circumstances, current wage moderation might be wholly or partly transitory; wage concessions today will be offset (or partially offset) by catch-up adjustments in the future. Once the catchup occurs, the basic wage-change process remains what it was in the past. Under both these outcomes, union wage change might well fall short of nonunion for a time-a break from the past as shown in table 1 .

The pattern of union contract concessions suggests that unions are hoping for partial recoupment of current concessions. Both the automobile and trucking contracts contain reopeners based on industry conditions. A sharp improvement in the condition of these industries could trigger new negotiations and a union attempt to recoup earlier losses. The General Motors and Ford contracts, moreover, have automatic (partial) recoupment provisions. Escalator payments are initially delayed, but are to be made up in the latter part of the agreement. The loss of the 3 percent annual improvement factor is not recouped. Thus $d<0 ; e>0$, but $-d>e$.

Situations like those in the trucking and automobile industries suggest realignments of the relative wage structure, not fundamental changes in wage determination processes. A true "turning point" in union wage determination would be marked by changes in the other coefficients of equation 1: $a, b$, and $c$. One such change, a fall in $a$, may have been taking place beginning in the mid-1970s. As already noted, the 3 percent real improvement factor began to erode during that period due to limits on escalator protection and other forms of creative accounting. The absence of this factor from the revised automobile and trucking contracts suggests that previous real wage improvements are no longer automatically expected.

A still more fundamental change would be an increase in the $b$ coefficient. A larger $b$ would imply that union wage settlements would become more sensitive to real business cycle conditions. For such a change to occur, at least one of three behavioral modifications would have to take place. The parties could cease to negotiate long-term contracts (or could place frequent reopeners in long-term contracts) and thereafter demonstrate substantial sensitivity in the resulting contracts of short duration to real business conditions. Or the parties could negotiate long-term contracts as they have in the past, but add to them contingency clauses sensitive to the business cycle. Thus a contract might contain a provision tying some element of compensation to profits, 
sales, output, or productivity (all cyclically sensitive) just as escalator clauses have tied compensation to movements in the CPI. Finally, the parties could negotiate long-term contracts as in the past, but correctly anticipate swings in business cycles and build wage responsiveness to those changes into the agreement.

The impact of a behavioral change in the $c$ coefficient is unclear. Theoretically it is often argued that the $c$ coefficient should be equal to 1 -that is, that bargaining should take place in real terms. However, it is in the long-term escalated agreements that the coefficient has come closest to equaling 1 . If contracts were to be shortened, or if escalator clauses were to be dropped, the $c$ coefficient might fall below unity. If $p$ is lagged, a drop in $c$ would suggest reduced inflation momentum; last period's inflation would have a smaller effect on current inflation.

There is reason to think that old tendencies in labor-management relations were based on strong motivational factors and that previous behavior captured by $b$ and $c$ tends to reassert itself in the absence of external intervention. The existence of the long-term contract is intimately tied to strike avoidance. In distressed times, both parties may be especially concerned about the impact of strikes and may be able to work out cooperative relationships without long-term contracts. The procyclical nature of strike incidence has long been noted in the labor economics literature. ${ }^{13}$ But ultimately there is no reason to suppose that long-term, inflation-sensitive contracts are a thing of the past.

To negotiate sensitive long-term contracts, either accurate forecasts must be made of the future course of economic events or contingency clauses must be added. Previous experience suggests that the one contingency clause that regularly has been built into contracts is the escalator. But contingencies based on events other than inflation have sometimes been included in contracts. Some union workers are covered by profit-sharing or other gain-sharing plans. Except in periods of concessions, unions have rarely demanded such plans, however. Apart from concessions, such plans were often established before the union came on the scene.

During periods of distress, gain-sharing arrangements, which effectively raise the $b$ coefficient, are sometimes put in place to make

13. Albert Rees, "Industrial Conflict and Business Fluctuations," Journal of Political Economy, vol. 60 (October 1952), pp. 371-82. 
concessions more palatable. For example, the 1982 Ford and General Motors contracts both contain profit sharing. In such times, gain sharing may really be loss sharing, but coupled with the hope that if conditions improve some recoupment of the loss may be possible. Gain-sharing plans are typically geared to the employer's economic condition and thus questions can be raised by the union concerning the accuracy of the index used. Such problems do not arise with escalator clauses because the CPI is published by a neutral government agency. Thus with gain sharing may come demands to open the employer's books to union scrutiny. When employers are suffering losses, they may be amenable to such demands; in more prosperous periods they may resist them.

Gain sharing may be accompanying demands for union participation in management. Although the firm's fortunes may depend heavily on general business cycle conditions, there can be a wide diversity of interfirm performance related to management quality and foresight. The historical record suggests that both cooperation between union and management and gain sharing are fostered during periods of distress. But such arrangements can erode when business improves.

In short, the current wave of wage concessions and renegotiations may well result in lower union wage levels-at least for a time-than past trends would have suggested. There may well be a change in the old 3-percent-plus-escalator formula toward a more modest goal. Indeed, this adaption may have already begun in the 1970s. A permanent shift to contracts of short duration seems unlikely as does a permanent increase in sensitivity to business cycle conditions (an increase in $b$ ). These conclusions assume there is no external intervention in the contract determination process and might be modified if the government did take a role in reshaping that process.

\section{The Public Policy Question}

A key issue for public policy is whether there should be some type of government intervention. In the recent past, intervention in bargaining has meant controls and guidelines. While some might argue that such intervention is still warranted-that government should reinforce the downward pressure on wages with suggested or mandatory ceilings for anti-inflationary purposes-the political prospects for such programs 
are nil. Nor is it evident that controls and guidelines would be desirable. But there have been suggestions that other forms of intervention should be contemplated.

Some observers have argued that long-term union contracts have contributed to wage rigidity in the United States relative to other countries. One recent proposal has called for a ban on long-term contracts and escalator clauses. ${ }^{14}$ In terms of equation 1 , such a proposal aims to raise the $b$ coefficient. This would mean that wage inflation would be more responsive to economic slack, thus raising the efficiency of demand restraint as an anti-inflationary device. However, a ban on long-term contracts would increase the frequency of negotiations and therefore the risk of strikes. Moreover, it is not clear how such a ban would be enforced. Even if long-term contracts were made legally nonbinding, parties would still be free to maintain a "gentlemen's agreement." Union contracts were not made legally enforceable in federal courts until the Taft-Hartley Act of 1947 and their status in state courts before that date was ambiguous in many jurisdictions. Contracts were made enforceable largely at the behest of management groups who wanted guaranteed periods of extended peace with labor. Yet the parties generally lived up to their agreements before the Taft-Hartley Act.

It might be possible to reinforce the tendency toward profit and gain sharing that has accompanied wage concessions. Currently profit-sharing plans enjoy tax advantages if their bonuses are used for retirement or other deferred purposes. If policymakers wanted to raise the sensitivity of wage change to business cycle conditions, broader tax incentives could be created to encourage gain-sharing arrangements. Such policy changes have worked in the past. For example, before World War II unions often opposed benefits such as employer-paid pensions. But they responded enthusiastically to the post-World War II tax incentives for pensions, life insurance, and health and welfare plans.

Apart from tax incentives, government agencies such as the Federal Mediation and Conciliation Service could play a role in fostering interest in gain-sharing plans. During World War II the National War Labor

14. Barry Bosworth, "Policy Choices for Controlling Inflation," in Controlling Inflation: Studies in Wage/Price Policy, Alternatives for the 1980's, 1 (Washington, D.C.: Center for Democratic Policy, 1981), pp. 16-22. See also Robert J. Gordon, "Why U.S. Wage and Employment Behavior Differs from That in Britain and Japan, "Working Paper 809 (National Bureau of Economic Research, 1981). 
Board played such an educational role with regard to various contractual arrangements like grievance arbitration. At present a combination of economic distress and concern about productivity and international competition has created a greater receptivity toward "new" ideas in labor-management relations. Ideas potentially linked to gain sharing, such as how to meet the Japanese challenge- "theory Z"- - the quality of work life, worker participation in management, and codetermination are currently under debate. ${ }^{15}$

The receptive climate for such experiments is fragile. If conditions improve, management loses interest. But deteriorating conditions can have the same effect on the union side. In the early 1930s union interest in labor-management cooperative experiments established in the 1920s quickly diminished in the face of growing worker anger and militancy. ${ }^{16}$ Thus federal reinforcement of plans for gain sharing may be crucial to their success. The Reagan administration has taken the position that there should be no intervention in the wage decisions of financially distressed industries or any others. Hence it is reasonable to assume that institutional changes in wage determination will not be deliberately encouraged in the near future.

\section{Possible Spillovers from Concessions}

An important issue in assessing short-term prospects for wage inflation is the degree to which the wage concessions in the distressed unionized industries will spill over into other wage decisions. Unionized employees account for only about one-fourth of all wage and salary earners. But to the extent that there is substantial spillover from union wage concessions to wages elsewhere, the effectiveness of monetary restraint in inducing disinflation will be enhanced.

Two kinds of spillover can be considered. First, will there be substantial spillover into areas of the union sector that are not facing severe threats of bankruptcy and permanent plant closings? The answer for any

15. Theory $\mathrm{Z}$ is described in William Ouchi, Theory $Z$ : How American Business Can Meet the Japanese Challenge (Addison-Wesley, 1981).

16. Sanford Jacoby, "Union-Management Cooperation: An Historical Perspective," Working Paper 32 (UCLA Institute of Industrial Relations, 1981). 
particular unionized unit will probably turn out to depend heavily on the extent of pattern following in the past. Spheres of union wage setting have been evident for many years. For example, wage settlements in automotive parts, truck manufacturing, and farm equipment have traditionally been patterned after the automobile settlements in the major firms. The basic wage settlements in the steel industry have been linked to settlements in smaller steel companies, nonferrous metals, and metal containers. Intercity trucking settlements have an influence on local trucking negotiations and on the settlements for truckers in retail food stores.

The key settlements are not imitated exactly in any of these patternfollowing situations. There may be variations in fringe benefits, the timing of wage adjustments, the precise formula used for the escalator, and in "noneconomic" areas such as work rules. In periods of distress, pattern following shows some tendency to erode. Thus when traditional spheres of imitation exist, current contract concessions in the key units may be expected to lead both to more diversity in the wage settlements within the sphere and to some spillover from the key settlements to the followers.

Union settlements outside the spheres of the distressed industries are likely to be reduced in 1982 relative to 1981 , but largely because of reduced inflationary pressures generally. Developments in the oil industry illustrates this trend. As shown in table 3, the 1980 settlements called for an annual rate of wage increase of 10.5 percent a year over two years with no escalator. The two-year oil contracts signed in early 1982 call for about 8 percent a year with an increase of 9 percent during the first year.

The second possibility of spillover is to wages in the nonunion sector. This possibility is especially important since about three-fourths of the paid work force is unorganized. There have been attempts to estimate econometrically the degree of spillover from union to nonunion and from nonunion to union by introducing into a wage-change equation a variable measuring the union-nonunion wage differential. A negative and significant coefficient for this variable in the union equation might be taken to indicate nonunion-to-union spillover. A positive and significant coefficient in the nonunion equation might suggest spillover in the opposite direction.

Using this technique, Johnson and Flanagan found evidence of 
nonunion-to-union spillovers but none running in the opposite direction. ${ }^{17}$ However, there are three problems with their interpretation of the statistical record. First, the results are not robust. Susan Vroman and I have shown that a change in the data source can reverse the results. Second, it is easy to show that relative wage coefficients in wage-change equations can represent a form of "regression to the mean." 18 If union and nonunion wage adjustments are determined by the same independent variables but do not interact, the relative wage variable is essentially a proxy for aberrant behavior in the past. By definition, aberrant behavior is eventually corrected, thus giving the relative wage coefficient significance and the expected sign. Third, other evidence suggests that nonunion pay is influenced by union wage developments.

There have been periodic case studies of nonunion firms that follow union pay patterns as a matter of policy. It is known that union wage concessions have already spilled over into nonunion decisions in the firms given the concessions. For example, during 1979-81, nonunion Chrysler workers were affected by the union wage freeze. Firms seeking wage concessions from unions are expected to have their executives and other nonunion personnel share in the sacrifice.

Some direct evidence exists concerning nonunion wage-setting practices. The Bureau of National Affairs (BNA) polls personnel executives, private and public, concerning various aspects of their wage and other policies. ${ }^{19}$ BNA found that the use of surveys of wages external to the employer was almost universal ( 93 percent), at least among firms large enough to enter the BNA sample in 1979-80. Of those employers that used wage surveys, 85 percent indicated that the resulting information was "very helpful" to "essential" in making wage decisions. The opinions expressed by large and small firms were quite similar. To the

17. George E. Johnson, "The Determination of Wages in the Union and Nonunion Sectors," British Journal of Industrial Relations, vol. 15 (July 1977), pp. 211-25; and Robert J. Flanagan, "Wage Interdependence in Unionized Labor Markets," BPEA, 1976:3, pp. 635-73.

18. Susan Vroman, "Union/Non-union Spillovers," and Daniel J. B. Mitchell, "Union/ Nonunion Spillovers: A Note,' British Journal of Industrial Relations, vol. 18 (November 1980), pp. 369-76; Daniel J. B. Mitchell, "How to Find Wage Spillovers (Where None Exist): A Note of Caution," Industrial Relations, forthcoming.

19. Bureau of National Affairs, Inc. Wage and Salary Administration, PPF Survey 131 (Washington, D.C.: BNA, 1981), p. 3; Bureau of National Affairs, Inc., Policies for Unorganized Employees, PPF Survey 125 (BNA, 1979), p. 13. 
extent that union wages are included in wage surveys taken by nonunion employers, some spillover is likely. In addition, certain public and government-funded private employers are legally required to follow the results of pay surveys that may be influenced by union wages.

Twenty-two percent of employers in the BNA survey in 1977-78 reported that they have a standard policy for their nonunion employees of matching or exceeding the wage settlements they reach for their unionized workers. Sixty-three percent indicated that they "reviewed" the relation between union and nonunion pay within their organizations, although 69 percent responded that they had no formal policy for adjusting nonunion wages based on their union settlements. Large firms, which contain a disproportionate fraction of the work force, seemed more likely to be influenced by union pay outcomes within their firms than small ones.

The limited evidence available suggests that union contract concessions will have a significant impact on the pay of nonunion workers in the enterprise receiving the concession. To some extent, nonunion employers will be influenced by union wage concessions-and union settlements generally-through their survey methodology. Purely nonunion employers, however, are less likely to be influenced by union concessions than those that are partially unionized.

Although the current rash of union wage concessions has past precedents, it is still an unusual episode. Thus there is danger in simply extrapolating from previous behavior established during "normal" periods. Perry has offered a model in which wage-adjustment "norms" develop in the labor market, and these may be influenced by special events or unusual economic developments. ${ }^{20}$ Because of the wide publicity given to recent union wage concessions in major industries, it is possible to argue that wage norms will shift in response. Unfortunately, reverse arguments are also easy to concoct. It could be argued that the concessions have been reported as unusual responses to exceptional circumstances and thus will not be seen as guides outside the distressed industries. Because the concept of norms is elusive, norm shifts cannot be readily predicted in advance.

Nonunion pay is rarely determined by explicit contract. However, it has become recognized in the economics literature that contract-like

20. Perry, "Inflation in Theory and Practice." 
regularities may exist in the nonunion sector. Some authors attribute these implicit contracts to turnover costs or to differential risk preferences between employers and employees. In addition, there is historical evidence that the threat of unionization played a role in encouraging the centralization and bureaucratization of the personnel function in modern corporations. ${ }^{21}$ More recently these tendencies have been reinforced by various regulatory policies in the labor market-most notably requirements for equal employment opportunity-which have injected the courts into personnel matters and added pressure for central control of personnel decisions. Finally, courts have begun to suggest that nonunion workers may be entitled to forms of "due process" previously required only in union contracts.

Thus, while nonunion pay may be more market-sensitive than union pay, contract-like regularities associated with bureaucratic decisionmaking can be expected to create some inflation momentum in wage setting. A survey of pay decisions planned for 1982 for salaried workers (largely nonunion) as of summer 1981 indicated that raises in the 9 percent range were being budgeted. By early 1982, however, surveys suggested that planned increases had been revised to the 8 percent range. ${ }^{22}$ This rate of increase is comparable to the annualized wage change negotiated in the oil settlement of January 1982 in the union sector. It is obviously easier to alter a proposed nonunion budget than a legally enforceable contract. But some inertia in nonunion pay decisions should be expected. Given the increases in social security taxes and continuing pressures of inflation on fringe-benefit costs in health care, forecasters in late 1981 and early 1982 were reluctant to project increases in compensation per hour of substantially less than 8 percent for $1982 .{ }^{23}$

21. Arthur M. Okun, Prices and Quantities: A Macroeconomic Analysis (Brookings Institution, 1981), chaps. 2 and 3; Martin Neil Baily, "Wages and Employment under Uncertain Demand," Review of Economic Studies, vol. 41 (January 1974), pp. 37-50; Robert E. Hall and David M. Lillien, "Efficient Wage Bargains under Uncertain Supply and Demand," American Economic Review, vol. 69 (December 1979), pp. 868-79; and Sanford Jacoby, "The 'Human Factor': An Historical Perspective on Internal Labor Markets in American Manufacturing Firms," Working Paper 21 (UCLA Institute of Industrial Relations, 1980).

22. American Compensation Association, 1981-1982 Salary Budget Survey (Scottsdale, Ariz.: ACA, 1981), p. 1; and "Survey Finds Companies Scaling Back Earlier Anticipated 1982 Salary Gains," Daily Labor Report, March 29, 1982, p. A3.

23. The December 1981 UCLA business forecast estimate for increases in compensation per hour in 1982 was 8.1 percent calculated year to year and 7.5 percent when 
The wage concessions themselves will have only a limited effect since the number of workers directly covered by concessions was probably less than two million. Even if it is assumed that these workers receive no wage increases in 1982 (an exaggeration because some concession contracts provide for increases) and that spillovers double the number of workers affected, the impact on overall wage adjustments is small. If four million workers were to receive no increases while others received an average 8 percent, the average adjustment would be reduced to about 7.6 percent.

Obviously it is possible that compensation per hour will rise by much less than the 8 percent forecast for 1982 . However, if that occurs it will either be because price inflation turned out to be substantially less than that forecast or because a substantial break from past wage behavior occurred-a norm shift. It can be said that there was no evidence of a sharp break from past behavior in the union sector during 1981 and early 1982. Table 6 presents the results of a survey by the Bureau of National Affairs, of median first-year union wage adjustments from 1978 through the first quarter of 1982 . These figures are distorted by the exclusion of escalator payments from the settlement estimates. More important, they are not a good measure of average wage changes because they represent median settlements, regardless of the number of workers covered by each settlement. But they do indicate how individual decisionmakers and bargainers were responding to economic developments.

Median wage settlements in manufacturing began to run at a flat 9 percent in 1980. The 1981 quarterly figures and the estimates for 1982:1 show no deviation from this pattern. Figures for nonmanufacturing excluding construction are more erratic but averaged 9.5 percent in 1980 and 1981. The drop in the first quarter of 1982 in these adjustments may reflect the direct inclusion of settlements linked to the Teamsters' intercity trucking concession, which was negotiated in late January, and to airline wage concessions; through January 1982 the figure was 9.5

calculated fourth quarter to fourth quarter. The Data Resources, Incorporated, forecast for the same figures as of January 1982 was 8.5 and 8.7 percent, respectively. The January 1982 forecast of Goldman Sachs and Company for compensation per hour was 9.4 and 9.3 percent. See UCLA Business Forecasting Project, The UCLA National Business Forecast (December 1981), table 1; Data Resources, Inc., The Data Resources Review of the U.S. Economy (January 1982), p. 1.8; Goldman Sachs and Co., Economic Research (January 1982), p. 4. 
Table 6. Union Wage Decisions: First-Year Median Wage Settlements, 1978-82 ${ }^{\text {a }}$

Percent increase

\begin{tabular}{cccc}
\hline $\begin{array}{c}\text { Year } \\
\text { or } \\
\text { quarter }\end{array}$ & $\begin{array}{c}\text { Nonmanu- } \\
\text { Manu- } \\
\text { facturing, } \\
\text { excluding } \\
\text { construction }\end{array}$ & Construction \\
\hline 1978 & 8.5 & 7.5 & 6.2 \\
1979 & 8.3 & 8.5 & 8.5 \\
1980 & 9.0 & 9.5 & 11.3 \\
1981 & 9.0 & 9.5 & 11.8 \\
$1981: 1$ & 9.0 & 9.8 & n.a. \\
$1981: 2$ & 9.0 & 9.0 & 11.6 \\
$1981: 3$ & 9.0 & 9.2 & 11.8 \\
$1981: 4$ & 9.0 & 9.6 & n.a. \\
$1982: 1$ & 9.0 & 8.3 & n.a. \\
\hline
\end{tabular}

Sources: Daily Labor Report, April 2, 1982, p. B1; Daily Labor Report, January 22, 1982, pp. B1, B2; and Bureau of National Affairs, Inc., 1981 and 1980 Briefing Sessions on Collective Bargaining (Washington, D.C.: BNA, 1981, 1980), p. 1 of both editions.

n.a. Not available.

a. The data exclude escalator payments and are not weighted by number of workers covered by each settlement. "First year" is defined as first ten months of contract. The survey includes settlements involving fifty or more workers.

percent. Construction settlements are too seasonal to appear except in the second and third quarters; but on an annual basis, construction wage agreements showed an accelerating rate of wage adjustments during 1978-81.

The imperturbability of the figures is remarkable in view of the accelerating pace of contract concessions beginning in 1979. In particular, during the fourth quarter of 1981 and first quarter of 1982 both the Teamsters and the UAW underwent a well-publicized period of soulsearching about reopening their contracts and finally agreed to do so. Apparently negotiators outside traditional spheres of wage imitation of these unions were not impressed.

\section{Summary and Conclusions}

Several lessons can be drawn about the recent rash of union wage concessions. First, similar episodes of concessions have occurred in the past, which suggest that permanent and fundamental changes in the processes of union wage determination are unlikely to result from the 
current concessions. Most important, the permanent abandonment of the long-term contract and the cost-of-living escalator is not likely to occur. The paper suggests that if it is socially desirable to introduce greater wage sensitivity to the business cycle into labor contracts, tax and other incentives to gain sharing should be considered.

Second, the history of union negotiations in the mid-1970s shows the importance of long-term contracts and their timing in determining the response of union wages to recession. Although the 1973-75 recession was severe, the major contracts had been essentially locked in during 1973 before the recession was apparent. The effect of timing can be overwhelmed, as the reopenings of contracts negotiated during 1979-80 clearly demonstrate. However, major concessions were possible in the period beginning in 1979 only because aggregate demand restraint and other, competitive, developments stemming from imports and deregulation pushed industries to the point that permanent job losses to senior union workers were threatened. Pressure for concessions was magnified by the steady widening of the union-nonunion wage differential that had occurred during the 1970s.

Third, by themselves the concessions will have only a small effect on movements in aggregate wages in 1982, since a relatively small fraction of the work force is directly involved. Forecasters in early 1982 expected increases in compensation per hour of about 8 percent for the year. A substantial reduction below that level could result from either a deceleration of price inflation that is sharper than expected or from a shift in wage norms. During the early part of 1982 , however, pay settlements for union workers outside the distressed industries showed little evidence of such a shift. 


\section{Discussion}

Albert ReEs suggested that the paper should have given more emphasis to two noncyclical factors in interpreting the recent round of contract concessions. The first is deregulation, which has put direct pressure on both the trucking and airline industries. The second is the secular rise in foreign competition, which has directly and indirectly threatened the steel, automobile, durable goods, and other industries. James Duesenberry recalled John Dunlop's analysis of wage reductions in the early 1930s, which showed that product market pressure, rather than high unemployment per se, was most closely associated with wage declines. Wages fell earliest and fastest in sectors in which product market problems were most acute, rather than in sectors that had generally high unemployment rates.

A major focus of the discussion was on the magnitude and significance of growing wage differentials between unionized and nonunionized workers. Martin Baily noted that, if an earlier historical relation between union and nonunion wage levels was to be restored, either union wages must slow or nonunion wages accelerate. The former appears to be occurring, but if this represents a restoration of a previous equilibrium, there is little likelihood of spillover that would generate comparable moderation in nonunion wages. Michael Wachter agreed with this analysis. He noted that union wages have typically risen relative to nonunion wages during economic downturns and fallen relatively during expansions. But the 1970 s were an exception to this pattern, in large measure because union wages were indexed to the consumer price index, which rose rapidly over the decade. The current recession seems to be restoring the historical relation of wages primarily by reductions in union wages. Duesenberry disagreed with Wachter's cyclical analysis of unionnonunion wage differentials and argued that there has been a secular rise in the differential since the depression, with breaks in this pattern only during the Second World War and the Korean and Vietnam wars. This means there is no "historical" relation between union and nonunion wages to which to return. Jeffrey Sachs noted that the growth in the union-nonunion differential has been an international phenomenon over 
the past seven years. He attributed this trend to the oil price shocks and the productivity slowdown, both of which shrank the scope for real wage increases. These shocks were rapidly translated into lower wages in more competitive markets for labor, but not in the unionized sector.

John Taylor argued that two types of concessions considered by Mitchell were quite different in their economic implications. First, unions negotiating a regularly scheduled wage contract may grant concessions in the form of lower than expected wage increases. Second, unions may agree to unscheduled reopenings of contracts in order to grant concessions. Only the latter type of concession reduces the rigidity of the current wage-setting process, and it is this rigidity that makes inflation so sticky. George Perry observed that Taylor's distinction was less important in a more general view of what caused inflation inertia. Even at normal reopening periods, settlements could be influenced by a range of developments and expectations. If these settlements now turn out to be unexpectedly moderate, it could help the whole disinflation process by influencing wage setting elsewhere. Alan Blinder wondered whether changes in the fraction of workers covered by escalator clauses are a barometer of wage developments generally. Mitchell said that changes in that fraction mainly reflect changes in the relative importance of industries in which escalators are already prevalent. Rees added that it is more common to make various kinds of adjustments to escalators rather than simply to abandon them. Recently the frequency of escalator adjustments has been reduced in some contracts. Mitchell noted that when concessions are made, unions have generally deferred COLA adjustments that are otherwise due while preserving the COLA provision for the future.

Several participants commented on the possibility that the current round of union concessions presaged a rapid deceleration in average wage inflation. Duesenberry noted that the rate of growth in average hourly earnings dropped sharply between fall 1981 and spring 1982. On the other hand, Mitchell reported that surveys of firms' intended wage increases were only 1 to 2 percentage points lower in March than they had been in September. Wachter suggested that the major union "givebacks" did not provide much inducement for nonunion workers to make similar concessions because nonunion workers had not shared in abovenormal wage increases in the 1970s. On the basis of recent experience, William Nordhaus reasoned that, as unemployment rose above a thresh- 
old level, it might have a growing impact on wage deceleration, perhaps because the median union worker becomes personally threatened by unemployment. Martin Feldstein added that it might not be the level of unemployment as much as the expected duration of high unemployment that is having the deflationary effect. 